\title{
«A Chain is gonna come». Building a penicillin production plant in post-war Italy
}

\author{
Mauro Capocci (*) \\ (*) Section of History of Medicine, Sapienza - Università di Roma, Italy. mauro.capocci@uniroma1.it
}

Dynamis

[0211-9536] 2011; 31 (2): 343-362
Fecha de recepción: 1 de marzo de 2010

Fecha de aceptación: 3 de febrero de 2011

SUMMARY: 1.-The Istituto Superiore di Sanità. 2.—UNRRA's plant and chain's penicillin. 3.-The ISS between business and politics. 4.-Conclusion.

ABSTRACT: In 1947, Ernst Chain moved from Oxford to Rome, hired as head of a new biochemistry department and of a penicillin production pilot plant in the Istituto Superiore di Sanità (Higher Health Institute). Here, he managed to make Rome one of the most important centres in the international network of antibiotic science. However, the development of the state-operated centre was not easy. Political and economic pressures, exerted both from home and abroad, posed many obstacles to the plan devised by Domenico Marotta, the general director of the Institute. The paper reconstructs Chain's venture in Rome, which lasted until 1964, while framing the history of the penicillin production plant in the context of diplomatic negotiations, national politics, and science policies.

KEY WORDS: Penicillin, Ernst Boris Chain, Istituto Superiore di Sanità, Domenico Marotta.

PALABRAS CLAVE: Penicilina, Ernst Boris Chain, Istituto Superiore di Sanità, Domenico Marotta.

\section{The Istituto Superiore di Sanità}

The Istituto Superiore di Sanità (Higher Health Institute, ISS from now on) is one of the most important biomedical research institutions in Italy ${ }^{1}$.

1. Historical accounts of the ISS can be found in: Paoloni, Giovanni. Il Laboratorio Chimico della Sanità. Dall'Istituto d'Igiene dell'Università di Roma all'Istituto Superiore di Sanità. In: Farina, Anna; Bedetti, Cecilia, eds. Microanalisi elementare organica. Collezione di strumenti. Roma: Istituto Superiore di Sanità; 2007, p. 9-61; Donelli, Gianfranco. La microscopia elettronica all'Istituto Superiore di Sanità dal 1942 al 1992: dai Laboratori di Fisica al Laboratorio di Ultrastrutture. Roma: Istituto Superiore di Sanità; 2008; Capocci, Mauro; Cozzoli, Daniele. The making of the Italian scientific research system: the case of Domenico Marotta (1886- 
Particularly in the decades after the Second World War, it became one of the state-funded institutions that provided a model for scientific research. It combined public health tasks with pure and applied research, and also had an important role in spreading innovations in the life sciences: biochemistry, biophysics and molecular biology all found in the ISS an important training and research centre in the 1950s and 1960s. This made the institute one of the engines of scientific development in post-war Italy.

Founded in 1934, it was the result of an agreement between the Italian government and the Rockefeller Foundation (RF). A few months after its opening, at the beginning of 1935, Domenico Marotta became its director: he would keep this position until his retirement in 1961. During this time, he managed to fully develop his vision, creating an institute able to compete at the international level, attracting important scientists from abroad, and finally creating a state-owned penicillin production plant.

The original mission of the ISS, as intended by the RF, was to pursue field work in the sector of public health, most likely similar to the endeavours the Foundation's Health Division undertook in the first decades of the twentieth century in underdeveloped countries (e.g., Mexico and Brazil) ${ }^{2}$. Accordingly, the first name of the ISS was Istituto di Sanità Pubblica (Institute of Public Health: the name was changed in 1942). RF was already present in Italy with a strong commitment in the fight against the «national disease», i.e. malaria; prevention of this and other scourges, together with general control and education tasks, was to be the main mission of the ISS, at least in the RF's opinion. The Fascist Regime (and Marotta) strove to make the institute a large research establishment, similar to the Institut Pasteur in Paris, or the Johns Hopkins Medical School in Baltimore: a national body for any sort of chemical, medical and physical tests (mostly on food, drugs and chemicals) as well as a centre for scientific research. The Institute would have been a symbol of the new powerful nation the Fascist dictatorship was creating. Yet, when the new institution was inaugurated in 1934 (on April $21^{\text {st }}$, the alleged day of the foundation of Rome) only a few facilities were actually in use, and in the next decade the Institute could not be fully devoted to

1974). Preprint of the Max Planck Institute for the History of Science. 2008; 361: 109-124. This paragraph is mainly based on the latter article, where detailed references can also be found.

2. Farley, John. To cast out disease: a history of the International Health Division of the Rockefeller Foundation (1913-1951). Oxford: Oxford University Press; 2004. 
research. In the second half of the 1930s, the colonial war and the militaristic policy of the Regime, as well as the ensuing embargo by the Society of Nations, resulted in an autarchic attitude and in the increased need by the Army for vaccines and drugs. As a consequence, the activities of the ISS were partly constrained: vaccines and sera production took a good deal of effort, as well as food chemistry and public health control duties. Some of the laboratories comprising the institute nonetheless carried out some research. Most notably, microbiology and bacteriology enjoyed the acquisition from Siemens of one of the few electron microscopes existing in Europe, and a particle accelerator was built, upon the request of Fermi's group. The physicists from the University of Rome turned to the rich ISS in order to build this important research tool, and Marotta gladly welcomed and satisfied their request. Unfortunately, the $1 \mathrm{MeV}$ Cockroft-Walton accelerator was only completed in 1939, after Fermi's flight and on the verge of war. Other important studies were developed by the malaria laboratory headed by Alberto Missiroli, related to the ecology of the anopheles and acquired immunity to the disease in humans.

The war hit Rome the hardest in 1943 and 1944, with repeated bombings by the Allies. In July 1943, a massive attack aimed at the railway lines hit streets and buildings in the university area. The ISS suffered some damage, but was still working. Another blow came when the Germans, in the spring of 1944, left the town and confiscated the electron microscope, considered to be a strategic instrument. A new one was built in 1946 by the scientists and technicians of the institute, allegedly following the plans stealthily copied in the days before the Nazi confiscation ${ }^{3}$.

After the war, in 1945, the ISS was one of the few existing and working scientific institutions in Italy. As the Institute was a technical and administrative body, it was quite easy for Marotta to avoid the recruitment of its personnel in the Army: the full functioning of the Institute was needed in order to produce important goods for the Nation. Marotta also managed to avoid the transfer of the Institute to the puppet state of the Repubblica Sociale Italiana, based in Northern Italy and under the Nazis' control. Like all the other offices of the government, the ISS was to be moved. Marotta cunningly allowed the transfer of just a few people, but not the infrastructures and the scientific instruments: he would have gladly agreed

3. Donelli, n. 1, p. 8-10. 
for the transfer, but only after the provision of a functional building, with all the laboratories properly working. In the hard times of 1944-1945, this was quite unlikely to happen, and Marotta added that Rome was a better location for providing drugs and other useful chemicals produced by the institute to the Southern regions.

Marotta was also able to pass relatively untouched to the new democracy; accused of being a collaborationist, due to the important role he had had within the fascist bureaucracy, he provided some evidence of his antifascist stance. As a matter of fact, he never overtly opposed the Regime, though it appears that he was not a fervent supporter of Mussolini, especially in the last few years of the dictatorship. He was thus allowed to keep his position ${ }^{4}$.

In the following years, Marotta could fully deploy his view of the ISS as a fundamental research centre, devoted to the scientific and technological development of the nation.

\section{UNRRA's plant and chain's penicillin}

Penicillin became a research subject in the Institute in 1944-1945. The alliance with the Nazis and the brutal consequences of the war most probably hindered the circulation of information regarding the new «miracle drug» before 1944: we know that even the more scientifically advanced Germany was quite late in attaching to penicillin its real value, though most of the publications were available in the Reich ${ }^{5}$. Germans apparently did not forward the information to their Italian allies; in Italy some news came across with literature from neutral Switzerland ${ }^{6}$. According to the head of the chemical department of the Milan-based pharmaceutical company Lepetit, «the

4. Marotta attitude towards the Fascist regime has been analyzed in Capocci, Mauro; Cozzoli, Daniele. The ISS during Fascism. Paper presented at the conference Science, scientist and totalitarian systems. Barcelona; 2008.

5. Shama, Gilbert; Reinarz, Jonathan. Allied intelligence reports on wartime German penicillin research and production. Historical Studies in Physical and Biological Sciences. 2002; 32 (2): 347-367; Wainwright, M. Hitler's penicillin. Perspectives in Biology and Medicine 2004; 47 (2): 189-98; Gaudillière, Jean-Paul; Gausemeier, Bernd. Molding national research systems: the introduction of penicillin to Germany and France. Osiris. 2005; 20: 180-202; Bud, Robert. Penicillin: triumph and tragedy. Oxford: Oxford University Press; 2007.

6. Farmitalia. La chimica della terra [motion picture]. Piavoli, Mario. ZefiroFilm, producer. 2008, 30 min, sound, color. 
study of penicillin in Italy began in early 1944» ${ }^{7}$. In July 1944, in the journal published by the Medical School of the University of Rome, Il Policlinico, an account of the new drug discovered by the Americans appeared, though the literature cited is largely incomplete ${ }^{8}$. In the same issue (p. 466), the journal bore a brief and unsigned note about penicillin treatment for gonococcal infection, reporting a study published in the Journal of American Medical Association in April 1944. In August, the physician Giuseppe La Cava of the University of Pisa, published a short review on the surgical uses of the new drug, based on the literature provided by the chief of public health services of the Allied Military Government ${ }^{9}$. In October (though published in February the next year), a study on 110 ophthalmological patients was described by a clinician at the University of Rome ${ }^{10}$; the source of penicillin was not mentioned. Another study involving penicillin was described in December 1944 and published in October 1945 by Roman physicians working in the Army Hospital (attached to the University General Hospital); the drug used was from Merck penicillin, «courtesy» of the American Army Command ${ }^{11}$. They treated two young soldiers, admitted in September and October 1944 for extensive burns. In the summer of that year, the Allied Committee controlling the Country presented two cultures of penicillin to the General Direction for Public Health, which gave them to the ISS ${ }^{12}$. The first studies conducted about the Penicillium mould were published in 1945 in the scientific journal of the Institute, the Rendiconti of the ISS ${ }^{13}$. These were several assays of the different methods for determining the

7. Carrara, Gino. L'industria farmaceutica italiana nel 1947 di fronte all'industria farmaceutica nel mondo. La Chimica e I'Industria. 1947; 29 (8-9): 208-210.

8. Jandolo, Costantino. Un nuovo chemioterapico: la penicillina. II Policlinico. Sezione pratica. 1944; 51 (27-31): 425-433. The Allied troops entered Rome on June 6th, 1944. Most probably, the paper had been written before the liberation of Rome, so that access to the literature was difficult.

9. La Cava, Giuseppe. La penicillina: sua storia, natura e applicazioni chirurgiche. II Policlinico. Sezione pratica. 1944; 51 (32-35): 473-476.

10. Bietti, G. B. La penicillina in oftalmologia. (Rassegna e contributi personali). II Policlinico. Sezione pratica. 1945; 52 (6-7, 8-9): 33-54, 74-78.

11. Corelli, F.; ladevaia, F. Moderno trattamento generale e locale delle ustioni. La cura dello shock da ustioni col lattato di sodio per bocca e della sepsi con la penicillina. II Policlinico. Sezione pratica. 1944; 52 (43-44): 457-467.

12. Per la produzione della penicillina in Italia. II Policlinico. Sezione pratica. 1944; 51 (32-35): 504.

13. Scanga, Franco. II controllo della sensibilità dei germi nella terapia penicillinica. Un metodo di ricerca semplice e di pratica applicazione. Rendiconti dell'Istituto Superiore di Sanità. 1945; 8: 485-510; Scanga, Franco. La concentrazione della penicillina nel sangue e negli altri 
concentration of penicillin in blood and urine according to various means of administration of the drug, and a long assay regarding the spectrum of activity of the antibiotic substance. Both papers are by Franco Scanga, head of the bacteriology laboratory and author of several studies on sulphamides before the war. He states in the papers to have used the Penicillium notatum strain nr. 1249, «the original one, coming from London» ${ }^{14}$. Scanga used the surface fermentation technique: it was the easiest and cheapest if only a small quantity was needed. In his papers, he also reviewed the existing literature and proposed two new simpler methods for testing the sensitivity of bacteria and assaying the concentration of penicillin in the blood and other body fluids. In September the same year, Alexander Fleming visited the Institute and lectured there. The speaker in a newsreel by the Istituto Luce $^{15}$ states that, once the rumour had spread that Fleming was in Rome, the cameramen went out searching for the penicillin discoverer: «it was easier for them to find the scientist, than a single dose of the powerful medicament» ${ }^{16}$.

Penicillin was still at the time a scarce resource ${ }^{17}$. Yet, in 1945 some technologies were already available for industrial production by deep fermentation, though only implemented in the USA and Canada. The United Nations Relief and Rehabilitation Administration (UNRRA), the US-dominated organisation aimed at relieving the damages of the war, set up a large scheme to provide penicillin to several countries in Europe. Italy was included in this program, first by direct import of the drug ${ }^{18}$, and later by the offer of a complete plant for production by deep fermentation. By means of a cable on 11 February 1946, UNRRA's mission in Rome was

liquidi organici. Importanza delle vie di somministrazione e del dosaggio. Metodi di ricerca. Rendiconti dell'Istituto Superiore di Sanità. 1945; 8: 511-542.

14. Scanga, n. 13, 1945, p. 486. Though Scanga omitted the prefix, most probably he is talking about the P. notatum NRRL-1249 strain, used by the British for surface culture in the first efforts to produce penicillin on large scale.

15. The Istituto Luce was the State owned institute for cinematographic information. Its archive is available on the web at www.archivioluce.it.

16. Ospite in Italia lo scienziato scopritore della penicillina Alexander Fleming [motion picture]. Luce, Istituto, producer. 1945, 00:21 secs, sound, black and white.

17. The story of its large scale production has been told in full detail by Hobby, Gladys L. Penicillin: meeting the challenge. New Haven: Yale University Press; 1985.

18. In mid-1945, UNRRA assigned to Italy for civilian use 2500 vials (each containing 100.000 OU) monthly, for five consecutive months. On this, La penicillina in Italia. II Policlinico. Sezione pratica. 1945; 52 (23-24): 231. 
informed of the offer. The information was then handed over to the Italian Commissioner for Public Health, Gino Bergami, and only in April was the ISS informed. The offer consisted of a deep-fermentation penicillin production plant, plus the know-how needed for operating the equipment and thus some training for scientists. A clause to be respected regarded the fate of the production: it was meant neither for export, nor for commercial sale. The Italian Commissioner for Hygiene and Public Health gladly accepted the gift. According to a later account made in 1948 by Marotta himself, Bergami tried to implant the factory in Northern Italy, in order to be near to the productive core of the country. Yet UNRRA explicitly stated that the furnishing of the apparatus had to be «justified by Govt as part program rehabilitation previously existing Govt operated biological producing institutes» ${ }^{19}$. For this reason, the ISS was probably the only suitable site for the new plant. At least another laboratory offered its premises for the penicillin factory: the State Quinine Laboratory in Turin, whose management wrote to the Prime Minister, to the High Committee for Hygiene and Public Health, to the Minister of Internal Affairs, to all the local authorities, in order to have it ${ }^{20}$. It is somewhat remarkable that the management's letter does not mention any official communication, anything like a public call for application; the information about the penicillin plant was obtained by newspaper articles. These articles reported on the decision (discussed in the Parliamentary commission in mid January, 1947) of adding 350 million ITL to the UNRRA fund, yet they did fail to inform the reader that the location for the factory was already chosen, and the commission was only deciding about the money to be added to the project.

In 1946, in fact, two ISS scientists had already spent several weeks in Toronto to obtain training in penicillin and fermentation biochemistry, in a plant similar to the one presented to Italy. Their training eventually proved of little use: the intended plant never went into operation.

Many reasons led to this apparent failure. On one side, many documents show that Marotta complained about the substantial disorganisation of the UNRRA shipping. There was neither a list of what was being sent, nor was the shipping made towards only one destination. Marotta was

19. Cable 01538, UNRRA Washington to UNRRA Rome, 11 Feb 1946. Rome, Archivio Centrale dello Stato (ACS) - series ISTISAN - Fabbrica di Penicillina (FP), box 24, folder 1/5.

20. Commissione interna del Laboratorio del chinino di Stato in Torino, letter to ACIS, 12 Feb 1947, Rome ACS - Presidenza del Consiglio dei Ministri (PCM) 55-58 no. 39792.23 1.1.2. 
quite unnerved, as were the US representatives of UNRRA, by the delays encountered by the project. The problems denounced by Marotta were in fact real, and to the shipping issues a location issue was added, because the ISS had to search for a suitable area in order to create the new factory. Once the area was located (a few hundred meters from the institute's main building), it had to be cleared of the people working and living there. This proved to take longer than expected.

Marotta had another reason to gain some time. Between the end of 1946 and the beginning of 1947 an Italian tour was organised for Ernst Boris Chain. The invitation to Rome had been the primer: in mid-August 1946 Marotta asked Chain to lecture at the ISS, and later in the same year the British Council and various local institutions arranged a series of lectures on penicillin and antibiotics in the late winter of 1947 in several Italian cities. During the negotiations for the Italian tour, Chain and Marotta started their formal collaboration: already in February of 1947 the Oxford chemist was paid 75,000 ITL for his «technical and scientific services provided in the design of the plants of the penicillin factory» ${ }^{21}$. According to Chain's recollection, his first answer to Marotta's request for advice was sharp:

«The opinion I gave him was that it was utterly uneconomical to put up the technically antiquated UNNRA plant and in view of the high efficiency of penicillin production by private industry there was no case for the State to interfere in this industry» 22 .

Instead, he suggested a radical change to the project. The UNRRA funds, he argued, would have been more useful if aimed at the creation of an international research centre in biochemistry that included all the necessities for research, including a pilot plant for fermentation. Marotta most probably discussed the new project with the Commissioner for Public Health and some members of the Government: an agreement was reached to create a factory, as agreed with UNRRA, and the pilot plant Chain

21. Document in ACS - ISTISAN FP, box 24, folder 3.

22. Chain, Ernst B. My Activities at the Istituto Superiore di Sanità. Wellcome Library, London; EBC Archive, Box 12, C13, p. 1. The manuscript was probably written by Chain himself in 1957/58. Being Chain's personal memories, we should not take them as a perfect reconstruction of what had actually happened. In fact, Chain's reconstruction sometimes does not coincide with other documentary sources. 
devised. He also managed to get additional funding from the government, amounting to 350 million ITL. This supplement was justified by the need for a new building and the land to be bought, though during the debate in the parliamentary commission the issue of scientific research was raised: was the new facility aimed solely at penicillin production, or was it going to be devoted to research? The Commissioner for Public Health in January 1947 gave assurance that the funds were not destined for generic research purposes, though they may also be used for «other researches, controls, etc. etc» ${ }^{23}$.

However, curiously enough, Chain's participation in the endeavour is never made clear in the letters and documents exchanged with the American and UNRRA representatives. The several long memoranda sent to the American cultural attaché fail to mention the hiring of, or even the counselling by, the Nobel prize winning scientist, one of the living symbols of the wonder drug. Neither is Chain's name ever raised in the correspondence with the government officers. This silence extended until late summer 1948, when it was finally made clear that Chain would be in charge of the new biochemical research centre attached to the penicillin factory.

In February 1948 the ceremony took place to lay the foundation stone of the new factory; the US Ambassador James Clement Dunn, together with the Italian Prime Minister Alcide De Gasperi, was there. The pictures also show Ernst Chain there, though in the reports his name is never associated with the endeavour, and he is there solely as being one of the great characters in the penicillin saga ${ }^{24}$. Similarly, the ambassador did not mention in his address the research facility and the experimental character of the "pilot plant», nor did Chain in his speech ${ }^{25}$. Dunn also noted the end of the same year as the date for the beginning of penicillin production. He was quite optimistic in his forecast. At the end of June, the Director of the US Foreign Aid Mission to Italy, Leon Dayton, appeared very upset at the limited development of the project, despite the US having granted 200 million ITL in advance. Dayton adds two points to his complaint. The first

23. Camera dei Deputati. Le commissioni della Costituente per l'esame dei Disegni di Legge. Rome; 1985, p. 366.

24. Many pictures of the event, as well as many others images about the history of the institute are held by the ISS photo archive. The pictures may be accessed via the following website: http://www.iss.it/arst/index.php?lang=1

25. Registrazione effettuata in occasione della cerimonia di posa della prima pietra dell'istituto italiano per la fabbricazione della penicillina, 1948, ACS - ISTISAN FP, box 24, folder 3. 
refers to the agreement signed by the Italian and US governments, in order to have all US financed projects in operation by June 30th 1948. The second is the fact that rumours were spreading of two penicillin factories being «under construction by private firms (...), one of which may be producing before the end of 1948 , the other in $1949{ }^{26}$.

\section{The ISS between business and politics}

Dayton was correct: in the following years two plants began to operate in Rome. One was constructed by the Laboratori Palma, acting as a subsidiary of the American pharmaceutical firm Squibb, on the northern side of the town ${ }^{27}$. The other one was named Leo, and located in the Eastern periphery: the know-how and patents for penicillin production came from the Danish company Løvens Kemiske Fabrik, whose technicians and scientists came to Rome in 1947 to build the plant and put it into operation ${ }^{28}$. The Leo company in Italy was owned by Giovanni Armenise, who also owned the influential newspaper Giornale d'Italia as well as an important private bank. He had also passed relatively untouched from Fascism to the new Republic, despite being a member of several fascist institutions. The negotiations between Armenise and the Danish partner were concluded in early 1947 and in the spring of the same year an agreement was already signed. The deal provided for an immediate payment of 500,000 Danish Crowns (slightly more than 100,000 USD) and exclusive sales in the following countries: Switzerland, Austria, Yugoslavia, Albania, Greece, Romania, Bulgaria, Iran,

26. Leon Dayton to the High Commissariat of Hygiene and Public Health, 29 Jun, 1948, ACS - ISTISAN FP, box 24, folder 5 .

27. Apparently, the Palma-Squibb plant also produced streptomycin (at least in 1952: see Ministero delle Finanze, letter to Alto Commissariato per I'Igiene e la Sanità (ACIS), 26 February 1952. ACS - PCM 55-58 no. 39792.23 1.1.2). It is not clear if it ever produced penicillin.

28. Larsen, Alfred. Har De lyst til at tage til Italien. Ballerup: Løvens kemiske Fabrik; 1995. Leo was also the first firm to apply for a penicillin factory construction in Spain, in June 1947. Santesmases, Maria-Jesus. Distributing penicillin: the clinic, the hero and industrial production in Spain, 1943-1952. In: Quirke, Viviane; Slinn, Judy, eds. Perspectives on twentieth-century pharmaceuticals. Oxford: Peter Lang; 2010, p. 91-117. 
Iraq, Turkey ${ }^{29}$. The Italian company was also obliged to pay the Danes a tenth of the revenues obtained ${ }^{30}$.

In this context, the ISS project for a State operated factory, directed by an outstanding scientist, was perceived as a potential obstacle. Thus, it is quite understandable why Marotta was so discreet about Chain's arrival. Furthermore, there was another reason for not blowing the horn. Chain was not at all a beloved figure in the US. As most of his biographers underline, he was denied the visa to enter the United States for many years, despite the Nobel Prize and endorsement from the World Health Organisation. The main reason for this friction is to be found in the fact that in the aftermath of WWII Chain had many contacts with Eastern European countries (such as Czechoslovakia and the USSR) regarding penicillin production. Yet Chain's behaviour was not dictated by ideological adherence: his perspective was rather economic. In addition, he was also outspokenly critical of the honours the US had paid to Alexander Fleming, and of the understatement of the role of the Oxford group in the making of the wonder drug ${ }^{31}$.

The worries about the supposed competition between the State-run factory and its private counterparts were not completely ill-founded. The ISS plant, in full gear, could produce quite a large quantity of penicillin, though less than the output claimed by the two privately operated factories $^{32}$. In addition, the ISS was limited by the non-commercial clause signed with UNRRA. Yet, the public factory could access a substantial share of the market, such as the Army, the public hospitals and the zoo-technical service centres. In May 1947, the director of Leo wrote to Marotta, wondering if

29. It shall be noted that none of these countries were in the US sphere of influence. As a matter of fact, in the immediate aftermaths of the Second World War, Leo was the most important competitor to US firms. However its relevance in the penicillin field somewhat faded as American influence grew over the years.

30. Letter from Cisitalia to ISS, 3 May, 1947. ACS - ISTISAN FP box 24, folder 5.

31. Bud, n. 5, chapter 3. Chain never missed the chance to underline that Fleming did not grasp the importance of his 1929 discovery of the mould's antibacterial activity, stating that most of the credit for the wonder drug was to be ascribed to the painstaking chemical work carried out in Oxford (and thus, by himself). Chain, Ernst B. A short history of the penicillin discovery from Fleming's early observations in 1929 to the present time. In: Parascandola, John, ed. The history of antibiotics. A symposium. Madison, WI: American Institute of the History of Pharmacy; 1980, p. 15-29.

32. Leo's plant had a declared output of 2,000 billions O.U./year, while Italy need was about of 80 billions or 300 billions (depending on the estimates). Squibb's (Palma) plant was declared to have a 480 billions OU/year potential. In 1955, the ISS plant produced 950 billions OU. 
the new penicillin factory of the ISS was going to be a hindrance on their new Italian-Danish endeavour. Marotta firmly denied this:

«We think that no interference shall be between the penicillin production plant to be set in this Institute, and any similar plant that may be set up by private companies. This, provided that the State will not decide to establish a production monopoly. But regarding this point, to our knowledge, the High Commissioner for Health and Public Health, Gino Bergami has already given precise assurances to the parliamentary commission» ${ }^{33}$.

In the same letter, though, Marotta also pointed to possible flaws in penicillin production by private firms, underlining the importance of official control over this production. This implied the need for a public body that would be able to compensate for potential shortcomings. Cisitalia's worries were not completely ill-founded, though, since the possibility of nationalising drug production always loomed. In 1951 a bill regarding the intervention of the State in the production of drugs was discussed at length, following a 1949 proposal by the socialist MP Umberto Pieraccini. The bill was never approved, thanks to the opposition from Government and widespread contempt from industry. The Chemical Industries Association in fact harshly protested against the «ignorant slanders» addressed against private companies during the parliamentary debate, affirming the «dignity and the rectitude of the national production industry» ${ }^{34}$.

As a matter of fact, in the field of antibiotics the competition between public and private firms never really took place. Leo Penicillina enjoyed a de facto monopoly in penicillin production. While many firms imported and packaged the drug in Italy, Leo alone was able to produce it on its premises. Leo's production began in 1949 ${ }^{35}$ : Fleming went there to visit the plant. With Chain only a few kilometres away from the Leo factory, Fleming's visit may be considered a display of the company's pride. In the next few years, Leo also took advantage of the high import levy imposed on penicillin: foreign antibiotics were thus more expensive than Italian supplies, though the production price was lower in the US and UK than in Italy. Furthermore, the National Committee for Prices (the body in charge

33. Marotta to Cisitalia, 20 May, 1947. Rome, ACS - ISTISAN FP box 24, folder 5.

34. Telegram from Associazione Nazionale Industria Chimica and Associazione Industriali ChimicoFarmaceutici to Prime Minister, 16 Nov 1951, ACS/PCM 48-50 no. 1.5.1 2041.10.26.

35. Larsen, n. 28. 
of setting the prices of some goods) based the base price on the Italian production cost: this meant that the import levy, based on the nominal value of the good, was extremely heavy for foreign companies, and that the Italian firm could be competitive, at least in the national market. The relatively small scale, and the cumbersome deal reached with the Danish company, implied a high production cost for Italian companies, which had to be compensated in the market. Confindustria (the national organisation representing Italian manufacturing and services companies) thus called for protection against the dumping actions by foreign firms, that «would make national production unfeasible» ${ }^{36}$. This lobbying pressure on the Government was clearly ascribed to Count Giovanni Armenise, at least by the Communist MP Luigi Preti ${ }^{37}$. Curiously enough, though somewhat usual in Italian politics, the protectionist attitude was heralded by the right wing parties (the Government), while the left opposed the import levy. According to the Christian Democrat MP Gaspare Pignatelli, it was peculiar to hear a communist call for an act that would have worsened Italian dependence on the USA ${ }^{38}$. It must also be noted that Pignatelli was a member of the stockholders council in the Banca Nazionale dell'Agricoltura, the private bank owned by Armenise.

The strong protection for Italian penicillin endured only until 1952, since in later years the import levy was lowered. Yet two years were probably enough for granting the Leo plant enough profits to repay the initial investment. Since the ISS started penicillin production in the same year, the de facto monopoly granted to Leo was also long enough to cause some shortcomings: in 1950-1951, the Korean war had led to a crunch in the penicillin export from the USA, with antibiotics being considered a strategic good. This had generated a relative shortage in many countries where local production and alternative supply channels were not available. In Italy, a harder situation regarded streptomycin (with no local manufacturers), whereas national production (i.e., Leo's product) managed to cover a fraction of the demand for penicillin. Still, scarcity was experienced for both medicaments until the state stepped in and bought the drugs from costly suppliers outside the USA. The emergency was rapidly overcome,

36. Letter from Confindustria to Prime Minister, 29 June, 1950. Rome ACS - PCM 55-58 no. 39792.23 1.1.2.

37. Camera dei Deputati (CD). Resoconto stenografico. 9 Jul 1952, p. 39748.

38. CD. Resoconto stenografico. Seduta pomeridiana, 28 Feb 1951, p. 26608. 
and in 1952 the High Commissariat for Hygiene and Public Health (ACIS) antibiotic reserves were fully restored.

In this situation, once the production at the ISS was ready to start in June 1952, the late entrance into the industrial penicillin market caused some difficulties. When the ISS was looking for potential buyers, the ACIS declined the offer because of the stocks bought in the preceding year; the public health and assistance institutions, as well as the national market, were fully provided with the antibiotic ${ }^{39}$.

It was also too late for the ISS to exert any form of price control, a function claimed to be one of the purposes of the penicillin plant when a new substantial fund ( 350 million ITL) was requested from the government in $1950-1951^{40}$. As a matter of fact, penicillin price dropped all over the world in a few months ${ }^{41}$ : in 1954 the Italians paid for their prescription «wonder drug» $18 \%$ more than the British, but $8 \%$ less than the French, 14\% less than the Spanish, and a significant $81 \%$ less than the West Germans ${ }^{42}$. Furthermore, Marotta's attempt to enter the commercial market, selling at least «the products of experiments ... that otherwise would be lost», did not yield any result ${ }^{43}$.

The ISS penicillin factory, at its inception, was thus framed within the two alternatives of protectionism and liberalism. The latter was supported by the USA, pushing for the free market, and thus helping the penetration of American companies, such as Squibb, and protecting their investments abroad. Protectionism was on the other hand the typical stance of Italian industry, dedicated as it was to creating a protected national environment helping its own competitiveness ${ }^{44}$. To an Italian businessman like Armenise (furthermore, one raised within the Fascist Regime), the role of the pilot plant and the biochemical laboratory headed by Chain at ISS as an innovation

39. Letter from ACIS to ISS, 23 Jun 1952. Rome, ACS - ISTISAN, series Amministrazione e Personale (AMM), box 127.

40. CD, Commissioni in sede legislativa, Undicesima commissione, 14 Mar 1951, p. 506.

41. The price tumbled very fast: in January 1947, 10 million units cost 21 USD; in 1952, 1.15 USD; in 1955, 0.44 USD. Steele, Henry. Patent restrictions and price competition in the ethical drugs industry. Journal of Industrial Economics. 1964; 12 (3): 198-223.

42. Valier, Valerio. I prezzi delle specialità medicinali in Italia e all'estero. Rassegna chimica. 1955; 7 (5): 5-14.

43. Letter from Marotta to ACIS. 9 Dec 1957. Rome, ACS - ISTISAN, series Direzione (DIR), box 79.

44. This opinion was also expressed in a veiled manner by Lepetit's chemist Gino Carrara in Carrara. L'industria farmaceutica italiana nel 1947 di fronte all'industria farmaceutica nel mondo. 
centre, a public research establishment created to boost Italian technological development, was hard to understand and to acknowledge. As a matter of fact, this innovation role was the overall result of the Marotta and Chain association, at least in its first decade. The Fabbrica and the research centre were contiguous, and Chain himself considered the coupling of a large scale industrial ward with the research centre as a major strength of the project ${ }^{45}$. The pilot plant was to serve innovation in industrial biotechnology and biochemistry, and the factory would immediately benefit from the engineering developments achieved by researchers and technicians. The strong focus on production and engineering was also at the core of the World Health Organisation's interest in the new ISS centre, that soon became the site for international training courses and educational activities in the field of antibiotics ${ }^{46}$. Many guests, both from Italy and abroad, came to visit the centre: what is more surprising is that these guests were not only academic scientists, but also researchers and technicians working in private companies (again, Italian and international, such as Beecham, Merck and Astra). Italian pharmaceutical industries greatly benefitted from cooperation with the ISS, and they gained an important place in the global antibiotics market. For example, an Italian firm managed to become the official supplier of tetracycline hydrochloride for the US Military Medical Supply Agency for three consecutive years, from 1958 to $1960^{47}$. Italian companies could boast low prices also because of the patent policy: drugs were not patentable in Italy until $1979^{48}$. The four largest Italian companies (Leo, Palma-Squibb, Lepetit, Farmitalia) overtly acknowledged Marotta's and the ISS' role in 1955, by presenting the Institute with a statue portraying Alexander Fleming, a few months after his death.

\footnotetext{
45. Chain, Ernst B. Aims and function of the International Research Centre of Chemical Microbiology, 1951. Wellcome Library, London; EBC Archive, Box 12, C10.

46. Expert Committee On Antibiotics. Report on the First Session. Geneva, 11-15 April. WHO Technical Report Series. 1950; 26: 1-12.

47. Steele, n. 41. The name of the company is not yet known, and thus it's not clear whether it benefitted from ISS cooperation.

48. Marotta directed a Governmental Commission about drug patentability, whose final report endorsed drug patents. Still, the interest of small pharmaceutical companies - those with no R\&D to be protected by patents - prevailed.
} 


\section{Conclusion}

A detailed discussion of the political and economic implications of the Penicillin factory established at the ISS is beyond the scope of this preprint. Yet, we can draw some conclusions about its importance.

On the one hand, the scientific heart of the matter must be underlined. In Chain's laboratory a fundamental result was obtained, isolating the 6-APA (6-Aminopenicillanic acid), i.e. the active core of all penicillins ${ }^{49}$. This result was also at the core of a bitter controversy with Beecham's laboratory, since Chain acted as a consultant for the British company, and two of its researchers spent several months in Rome. Beecham thus took advantage of Chain's work to secure an important advance in the production of semi-synthetic penicillins. Furthermore, many technological innovations were implemented, thanks to the very skilful engineers working side-byside with Chain, especially in creating a completely controlled cycle of fermentation, where every step of the process was carefully monitored. The rate of failed fermentation was thus lower than with the traditional processes. The engineers that helped Chain in creating the plant were also responsible for the next centre where Chain moved after leaving Rome, the new biochemical laboratory (with a pilot plant for fermentation studies) at Imperial College, London. While in Rome, Chain also patented some important analytical instruments (a two-dimensional chromatographer, built within the Institute workshops), and broadened his research, including many aspects of carbohydrate metabolism. A lot of other important research was carried out by Chain's collaborators, ranging from microbial genetics to many aspects of biochemistry and fermentation ${ }^{50}$.

49. Ballio, A. et al. Penicillin derivatives of p-aminobenzylpenicillin. Nature. 1959; 183 (4655): 180-181 Batchelor. F. R. et al. Synthesis of penicillin: 6-aminopenicillanic acid in penicillin fermentations. Nature. 1959; 183 (4656): 257-8. For a later account of the discovery, though only from the British side: Rolinson, G. N.; Geddes, A. M. The 50th anniversary of the discovery of 6-aminopenicillanic acid (6-APA). International Journal of Antimicrobial Agents 2007; 29 (1): 3-8.

50. Following Bud's suggestion, for a detailed account of Chain's scientific activity we point at Abraham, Edward. Ernst Boris Chain. 19 June 1906-12 August 1979. Biographical memoirs of Fellows of the Royal Society. 1983; 29: 43-91. With regard to the work carried on in the ISS International Centre of Biological Chemistry, the reader may turn to Gualandi, Giuseppe. Il Centro Internazionale di Chimica Microbiologica ed il suo capo: E. B. Chain. Rendiconti dell'Accademia Nazionale delle Scienze detta dei XL. Memorie di Scienze Fisiche e Naturali. 1999; 5th series, 23 (2nd part, t. 1): 211-213 and Capocci and Cozzoli, n. 1. 
On the other hand, we point out the character of the ISS as a possible node of a network of innovation within the Italian technological environment. Still, soon after Chain left in 1961 (though he officially resigned only in 1964), the ISS entered a crisis, following Marotta's retirement and the legal prosecution that involved his management in 1964, and even involved Chain and the centre he directed. The Institute's role as an innovation spreader was lost, while the last evidence of activity for the pilot plant is found in the spring of 1964, in the middle of the storm that was hitting the institute. Harsh criticisms were directed against Marotta's and Chain's vision of the ISS and consequently of the penicillin plant ${ }^{51}$. Marotta was accused of having perverted the primary mission of the ISS, which had to be focussed on public health. In this view, repeatedly expressed by the ISS microbiologist Giuseppe Penso ${ }^{52}$, the role of technological innovation in biomedical sciences was not part of this mission, but only the result of Marotta's own grandeur. Still, the penicillin production plant may be framed in a larger context. Marotta used it in order to obtain some autonomy for the Institute, striving to overcome the bureaucracy that burdened every state-controlled activity. Penicillin was thus a key: the importance of the drugs allowed him to request money as well as to quickly hire scientific personnel, without the lengthy procedures requested for any other appointment within the Italian administrative and academic system. Marotta thus tried to shape the ISS according to Anglo-American fashion. At the same time, the state-owned penicillin production plant was probably considered by the government as a means to gain importance within the wider international context, just like the AGIP and later ENI (Ente Nazionale Idrocarburi), the national body for hydrocarbons, which in the same period became one of the most important players in the global oil market), although on a smaller scale ${ }^{53}$. The same forces were acting in the international scene where Marotta was playing, exploiting the American aids and at the same time gaining autonomy

51. The documents regarding the discussion about the fate of the penicillin plant are in ACS ISTISAN DIR, boxes 79 and 86.

52. Penso, Giuseppe. L'Itstituto Superiore di Sanita' delle origini a oggi. Esegesi storica e prospettive per il futuro. Roma: Tipografia regionale; 1964. Penso was one of the two scientists sent to Toronto for the penicillin training in 1947.

53. On the history of ENI a vast bibliography is available, though mostly in Italian. A recent account in English language is Carnevali, Francesca. State enterprise and Italy's «economic miracle»: the Ente Nazionale Idrocarburi, 1945-1962. Enterprise and Society. 2000; 1: 249-278. 
from the US at a crucial moment for the country ${ }^{54}$. The overall history of penicillin production also fits quite well in the wider frame of the policies enforced in Italy after WWII with regard to industrial production, as well as the strategies followed in the integration into the international economic system. These strategies have been termed as «liberal protectionism», and to many historians seems a weak compromise. On one side, the Government tried to follow the American-sponsored liberalism; on the other, it tried to protect some specific interests and to establish some sort of general welfare protection ${ }^{55}$.

At least in the early post-war years, the industrial compound was

«unable, with few exceptions, to think their international placing in an strategic perspective, wary if not overtly hostile to American directives for liberalization, these being accepted only for the part that allowed the immediate, though short term, boost of traditional exports, or when it favoured the flight of capital and speculations on currency exchange; yet, it was reluctant when confronted with the possibility of opening the national market ${ }^{56}$.

At the same time, until the beginning of the 1950s, the government was not able to develop a consistent economic and industrial policy. A sound planning only emerged in the middle of the decade, with the so-called piano Vanoni, the project designed in 1954 by the Government to help the development of Italian economy and society by means of strong intervention by the state in specific, though wide, sectors ${ }^{57}$. The reforms undertaken at the beginning of the 1950s and the new scene of the European Common Market (with the new trade and tariff system) caused the decline of overt protectionism. In this scene, the country entered a period of wild expansion,

54. In April 1948, the first general elections were held: the defeat of the Communist Party firmly placed the Country in the Western Block.

55. This opinion is largely shared. See for example Amato, Giuliano, ed. II governo dell'industria in Italia. Testi e documenti. Bologna: II Mulino; 1972; Cavalcanti, Maria Luisa. La politica commerciale italiana, 1945-1952. Uomini e fatti. Napoli: Edizioni scientifiche italiane; 1984; Battilossi, Stefano. L'Italia nel sistema economico internazionale. II management dell'integrazione. Finanza, industria e istituzioni, 1945-1955. Milano: FrancoAngeli; 1996.

56. Battilossi, n. 55, p. 50.

57. The «piano» was an ample theoretical scheme commissioned by the minister of the treasury Ezio Vanoni and elaborated by a think tank in 1954. A main objective of the plan was the filling of the wide gap between the North and the South of Italy. About Ezio Vanoni and his plan, a comprehensive picture is provided by the first issue of the Rivista SSEF, 2004 (available at http://rivista.ssef.it/site.php?page=\&edition=2004-01-01). 
the so-called «boom» or «economic miracle». The end of this expansion, due to several factors and usually situated in 1963-1964, overlaps the onset of a new reformist period. In 1962 Italy came to be ruled by a centre-left government, which called for stronger state control over the economy and nationalised some important sectors, such as electricity.

The crisis at the ISS and the penicillin factory largely overlapped with a general crisis experienced by the country. The economy slowed down after the boom, social issues related to modernization became manifest, and the North-South gap widened. The centre-left alliance proved unable to face the new challenges and also had to stand up against attacks coming both from the left and the right wing opposition. The prosecutions against Ippolito and Marotta should be framed in this context, and the new government failed to develop a new science policy and to fruitfully address the relationship between industry and science. This led in turn to a general crisis in the Italian research system that exploded harshly at the end of the decade ${ }^{58}$.

The various stages and steps that led to the steep decline in Italian science after the 1960 s are not yet fully detailed ${ }^{59}$ : thus it is not possible to draw a comprehensive picture framing the history of scientific institutions in the recent history of the country. However, the history of the penicillin factory ${ }^{60}$ offers an interesting perspective combining the big picture and the interaction among single characters. On one hand, the history of the penicillin factory is fully embedded in the history of Italy in that period: reconstruction, expansion, crisis. On the other hand, the creation of the factory was not a mere accessory or a consequence: people like Domenico Marotta and Ernst Chain had a vision of the development of science, and actively pursued it within an international network of people, institutions and ideas, thus trespassing the boundaries of «plain» national politics.

58. Ruberti, Antonio. Riflessioni sul sistema della ricerca dopo il 1945. In: Simili, Raffaella, ed. Ricerca e istituzioni scientifiche in Italia. Roma: Laterza; 1998, p. 213-230; Capocci, Mauro; Corbellini, Gilberto. Adriano Buzzati-Traverso and the foundation of the International Laboratory of Genetics and Biophysics in Naples (1962-1969). Stud. Hist. Phil. Biol. \& Biomed. Sci. 2002; 33 : 367-391; Capocci, Mauro. The golden age of human genetics in Italy. Journal of Anthropological Sciences. 2006; 84: 85-95.

59. An attempt at reconstructing this history is in Paoloni, Gianni. II sistema della ricerca nell'Italia del Novecento. Aspetti istituzionali e storico-politici. Paper presented at the conference La ricerca scientifica in Italia, Napoli, 2003; available at http://www.unisi.it/criss/download/ marcia2004/paoloni.pdf.

60. Although I must underline that this reconstruction is still a work in progress: many issues haven't been faced yet. 
Ernst Chain took part in the recovery of the country after the war, making Rome a «central periphery» ${ }^{61}$ for his own research fields. In this respect, may Chain's role be considered as a part of the foreign aid after WWII, just like the penicillin factory donated by UNRRA? Clearly this is not the case: science is not merely the continuation of politics by other means. As we have seen, the political situation allowed Marotta to fully deploy his vision of a great biomedical institution, in many ways connected to the surrounding society. He shall be credited for his belief in the value-added of science for the development of the country. Still, scientific history should be framed in the general picture in order to understand the causes of certain choices, of certain successes and setbacks. The penicillin factory, with its scientific, industrial and cultural content, is a good subject to investigate how science and politics related to each other in post-war Italy.

\section{Acknowledgments}

This paper is the partial result of a research project conducted jointly with Dr. Daniele Cozzoli (Universitat Pompeu Fabra, Barcelona). I owe him several interesting suggestions and fruitful criticisms. I wish to thank Dr. Fabio De Sio (The Wellcome Trust Centre for the History of Medicine at UCL, London) for useful comments. However, all the shortcomings of this paper are entirely under my responsibility. I also would like to thank Maria Pia De Simone (ACS), Donatella Gentili (ISS Library) and the staff of the Archives and Manuscripts Collection of the Wellcome Library (London) for the kind help provided, as well as the Leo Pharma Archive for providing some documents.

61. Gemelli, Giuliana. A central periphery: the Naples Stazione Zoologica as an «attractor». In: Schneider, William H., ed. Rockefeller philanthropy and modern biomedicine: international initiatives from World War I to the Cold War. Bloomington: Indiana University Press; 2002, p. 184-207. 